\title{
EFFECTS OF LONGER SPAN FLOOR SYSTEM IN THE CONSTANCY OF THE MULTISTORIED STRUCTURE: A COMPARATIVE STUDY
}

\author{
Md. Mahbub-ul-Alam', Farjana Akter² \\ ${ }^{1}$ Assistant Professor, Department of Civil Engineering, Stamford University Bangladesh, Dhaka, Bangladesh; \\ engineer_alam@yahoo.com \\ ${ }^{2}$ Lecturer, Department of Civil Engineering, Stamford University Bangladesh, Dhaka, Bangladesh. \\ farjanaakter.ce@gmail.com
}

\begin{abstract}
The main objective of this study is to investigate the structural integrity, stability and their comparison due to the effects of longer span floor systems considering some constancy in the multi-storied commercial and residential mixed-used structures. In recent times, mixed-use developments and buildings have created an up surging demand in perspective of relatively small area of lands like Bangladesh. But, the commercial developments consisting of underground basement required maximize serviceable column free open-floor spaces for more flexibility, marketability and uninterrupted executive car parking of the end-users. Now, the column free open-plan floor spaces, usually ranges from 18 27 ft, even up to $45 \mathrm{ft}$. or more [5], offers a bulky change in span length of the slab that results the longer span structure. Again, the longer span structure is directly related with the beam length which promptly affects the thickness of the slab as well as the sizes of beams, columns and the foundations. In this study, two different span lengths of the mixed-use structural Models are considered based on the economical range [18ft-30ft] of the RC floor systems. Then, both of the structural Models are compared based on the following parameters: design aspects, reduction in the number of components, sizes \& thickness, weight of steel and volume of concrete. It is found that, longer span structure keeps highest effects on the RC columns and increase in size by 104.3\%. This study will also be helpful for a designer to select an appropriate size of the structural components within the economical ranges of these types of particular RC structures in future
\end{abstract}

Keywords: Regular Span Structure, Longer Span Structure, Flat Plate Slab, Flat Slab, Edge Supported Slab Andmat Foundation.

\section{INTRODUCTION}

Concrete floor systems offer the designer a wide variety of options from which to choose a floor system for a particular project. Traditionally, column spacing and floor spans in many buildings have been seen close enough with each other producing small spans, to both contain costs and simplify construction. However, recently there is an increasing preference by building owners and tenants for large floor areas with column-free space and large spans. This has focused the interest of designers and builders on methods of reducing costs and speeding construction of long-span floors [5].

The aim in the structural design of long-span floors is to provide a serviceable and economical floor structure. The floor must meet the client's needs as set out in the brief and also reflect community expectations for safety, amenity and environmental impacts. A serviceable long-span floor is one that has sufficient strength to carry the permanent and imposed actions as well having adequate stiffness to limit deflection and vibrations. It must have the required resistance against fire, be durable, and be visually acceptable, if exposed to view. The floor may also have to resist actions other than vertical actions and meet other design criteria such as water tightness or chemical resistance. The aspects of durability and fire resistance, while requiring careful consideration, are not peculiar to long-span floor systems. An economical long-span floor is one that optimizes the material and labor costs. Minimum weight does not necessarily result in the lowest cost.

In recent years, the trend is the construction of mixed-uses structures as limited natural resources, the expenses, time and stresses of commuting draw people back into the city center. As a result, urban centers include now mostly structures with a storefront next to the street, offices in the stories immediately above, and, finally in the upper levels, apartments for city dwellers. But these types of buildings are difficult to arrange to take total advantage of structural and mechanical systems. Offices need large open spaces with large loads from mechanical and electrical systems. The living quarters, with their more intimate spaces, need closer column spacing, and have fewer vents and wires required meeting needs of comfort. Shallow floor-to-floor heights in the apartment areas are possible since they can be accommodated by a flat plate/flat slab design. According to the need of rentable spaces, owner desires, aesthetics, cost, safety and comfort, architects and engineers are now facing the challenges of structural design to accommodate people's total daily life in one single structure. As outcomes, multiplan and multifunctional structures are now being constructed with different types of concrete floor systems with longer spans. 


\subsection{Objectives of the Study}

1. To make a comparative study of regular and longer span structure having different floor systems i.e. flat plate, flat slab and edge supported slab

2. To determine the effects of longer span compare to regular span in shear and moment at different locations of the structures.

3. To identify the effects of longer span floor system on the member dimensions and required steel areas compare to regular span floor system.

\section{METHODOLOGY}

The study was conducted on the two ten storied commercial cum residential mixed-use frame structures. The structures were classified into two models,

Model-A: The structure having regular span witheach panel of $20^{\prime}-0^{\prime \prime} \times 18^{\prime}-0^{\prime \prime}$ size.

Model-B: The structure having longer span with each panel of $33^{\prime}-4^{\prime \prime} \times 30^{\prime}-0^{\prime \prime}$ size.

Based on ultimate load carrying capacity and design considerations, different tied columns were provided for different facilities of the structure which are summarized in Table-1 \& Table-2. As standard amenities and modern facilities, passenger lifts, basement, stairs, ramps etc. were considered in design of this structure. The both models were analyzed by STAAD Pro. Software and designed by ultimate strength design (USD) method [1, 2, 6, 7].Finally, based on the study, few concluding remarks and recommendations were drawn for carrying out further study.

\section{MATERIAL PROPERTIES AND LOADINGS}

The whole study was carried out based on the considerations and specifications which are summarized in Table-3.

\section{DESIGN OF MODEL-A \& MODEL-B}

All the slab panels of Model-A and Model-B have been analyzed and designed by the 'Direct Design Method'. Bar arrangement, cut-off, and bar spacing etc. are executed as per ACI/BNBC Codes [3, 8] provisions. The column layouts of Model-A and Model-B are shown in Fig-1. For a single corner panel $\mathrm{S}-1$, the slab reinforcement arrangement for both models at basement, shopping mall and residential parts are presented in Fig-2, Fig-3 and Fig-4 sequentially. All floor beams and columns of both models have been designed by considering both effects of gravity and lateral loadings according to the ACI code 2011 and BNBC 1993 $[8,3]$. The design moment is obtained from the analysis of STAAD Pro software. The assumed size of the column was verified according to the Reciprocal Method. The foundation system of both models is mat which would serve the basement floor for car parking, generator and store rooms' facilities. The total thickness of the mat was determined considering punching effects caused by columns subjected to heavy axial loads. The reinforcement details of the beamframes 1 6 of Model-A and frames 1 4 of Model-B; the sections of loaded column C-2 of both models, sections of mat foundation for Model-A and B are shown in Fig-5, Fig6, Fig-7, Fig-8, Fig-9 and Fig-10 successively.

\section{RESULTS AND DISCUSSIONS}

In this section, a comparative results and discussions are made based on different criteria between two structural Model-A \& B and summarized in Fig-11 Fig-15.

From Fig-2 Fig-4, it is observed that amount of total areas of reinforcing bars for all slab panels is lower in longer span structure compared to regular span structure. Similar things are found in case of mat steel requirement (Fig-9 \& Fig-10).

From Table-4, it is observed that, Cross sectional dimensions, volume of concrete and steel all are higher in Model-B than Model-A. This is because of that longer span length of Model-B produces higher values of moments and shears. The eccentricity of mat is higher than Model-A for approximately same live loads to be resisted. It is also noticeable that car parking's are increased by number four that is very much desirable.

In Fig-11, total number of slab panels of regular span structure which is 204 nos. has significantly reduced to 50 nos. of panels of longer span structure. Similarly, number of beams and columns are also decreased. These may lower the formworks as well as labor costs in case of longer span structures. Again it is observed that car parking capacity has increased compared to regular span structure which may lead to solving car parking problems.

From Fig-12 Fig-14, It is easily shown that, longer span structure demands larger thickness in slab, drop panels, mat etc. and greater dimensions for beams, columns etc. which produces higher volume of concrete and steel works compared to regular span structure and this may increase the project cost.

\section{CONCLUSIONS}

From the results and discussions, it is observed that:

1. Longer span floor system may offer more free floor spaces than regular short spans as the number of columns has reduced. This may help in providing better services.

2. Amount of total areas of reinforcing bars for all slab panels is higher in longer span structure compared to regular span structure. Similar things are found in case of mat steel requirement.

3. Longer span structure demands larger thickness in slab, drop panels, mat etc. and greater dimensions for beams, columns etc. which produces higher volume of concrete and steel works compared to regular span structure and this may increase the project cost.

4. Total number of slab panels of regular span structure which is 204 nos. has significantly reduced to 50 nos. of panels of longer span structure. Similarly, number of beams and columns are also decreased. These may lower the formworks as well as labor costs in case of longer span structures and also project period may decrease.

5. Car parking capacity has increased compared to regular span structure which may lead to solving car parking problems. 


\section{REFERENCES}

[1]Ferguson P. M., Breen J. E. and Jirsa J. O. (1987), "Reinforced Concrete Fundamentals", 5 ${ }^{\text {th }}$ Edition, John Wiley \& Sons, Inc., New York.

[2] Smith B.S. and Coull A. (1991), "Tall Building Structures", John Wiley \& Sons, Inc., New York.

[3] BNBC (1993), "Bangladesh National Building Code", $1^{\text {st }}$ Edition, City Art Press, Dhaka, Bangladesh.

[4] Easterling, W.S. (2002), "Long Span Composite Slabs Extending The Reach of Steel Construction." Proc. North.

[5] Standards Australia (2003), "Guide to Long-Span Concrete Floors", ISBN 1-877023-09-4, Cement and

Concrete Association of Australia, Australia.

[6] Everard N. J. (2004), "Reinforced Concrete Design", 3 rd

Edition, SCHAUM'S outlines, Tata McGraw-Hill

Publishing Company Ltd, New Delhi, India.

[7] A. H., Darwin D. and Dolan, C. W. Nilson (2006), "Design of Concrete Structures", $13^{\text {th }}$ Edition, McGraw-Hill Publishing Company Ltd, New Delhi, India.

[8] ACI (2011), "American Concrete Institute Building Design Code", ACI, New York, USA.

\section{LIST OF TABLES}

Table-1: Details of Model-A and Model-B

\begin{tabular}{|l|l|l|l|}
\hline \multicolumn{1}{|c|}{ Items } & \multicolumn{1}{|c|}{ Underground Basement } & \multicolumn{1}{c|}{ Shopping Mall } & \multicolumn{1}{c|}{ Residential spaces } \\
\hline Floors & Ground Floor & from $1^{\text {st }}$ to $3^{\text {rd }}$ floor & from $4^{\text {th }}$ to $9^{\text {th }}$ \\
\hline Slab Systems & Flat slab with column capita & Edge supported slab & Flat plate slab \\
\hline Column types & Spiral column & Tied column & Tied column \\
\hline
\end{tabular}

Table-2: Details of Structural Elements of Model-A and Model-B

\begin{tabular}{|l|c|c|}
\hline \multicolumn{1}{|c|}{ Items } & Model-A & Model-B \\
\hline Panel Size & $20^{\prime}-0^{\prime \prime} \times 18^{\prime}-0^{\prime \prime}$ & $33^{\prime}-4^{\prime \prime} \times 18^{\prime}-0^{\prime \prime}$ \\
\hline Column Capita Size, & $2 '-8^{\prime \prime} \times 3^{\prime}-2^{\prime \prime}$ & $2^{\prime}-2.5^{\prime \prime} \times 2^{\prime}-2.5^{\prime \prime}$ \\
\hline Spiral Column Size, C1 & $23^{\prime \prime}$ Dia & $47^{\prime \prime}$ Dia \\
\hline Tied Column Size, C2 & $14^{\prime \prime} \times 16^{\prime \prime}$ & $18^{\prime \prime} \times 22^{\prime \prime}$ \\
\hline
\end{tabular}

Table-3: Summary of the design considerations and specification of the study

\begin{tabular}{|c|c|}
\hline Items & Description \\
\hline Design code & $\begin{array}{l}\text { - } \quad \text { American Concrete Institute (ACI) Building design code, } 2011 . \\
\text { - } \quad \text { Bangladesh National Building Code (BNBC), } 1993 .\end{array}$ \\
\hline Loadings & $\begin{array}{l}\text { - } \quad \text { Floor plus ceiling finish }=30 \mathrm{psf} \\
\text { - } \quad \text { Live load }=150 \mathrm{psf} \text { for Ground to third floor } \\
\text { - } \quad \text { Live load }=40 \mathrm{psf} \text { for fourth to ninth floor } \\
\text { - } \quad \text { Earthquake and wind load are considered as per BNBC. }\end{array}$ \\
\hline Building components & $\begin{array}{ll}\text { - } & \text { Column type }=\text { Tied and Spiral } \\
\text { - } & \text { Footing type = Mat foundation. } \\
\text { - } & \text { Thickness of all walls = } 5 \text { inch. }\end{array}$ \\
\hline Material properties & 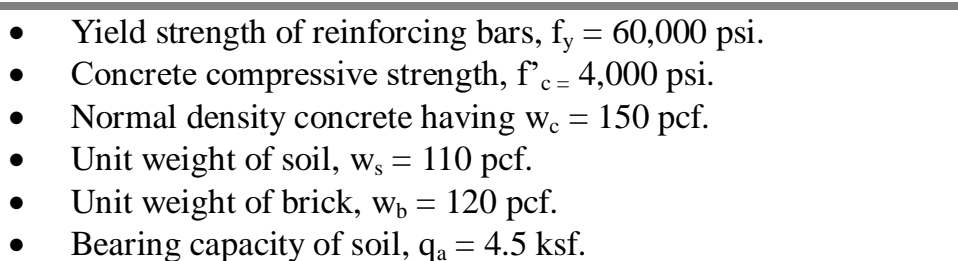 \\
\hline
\end{tabular}


Table-4: Comparison based on design aspects between Model-A \& Model-B

\begin{tabular}{|c|c|c|c|c|c|}
\hline \multirow{2}{*}{$\begin{array}{c}\text { Components/ } \\
\text { Elements }\end{array}$} & \multirow{2}{*}{$\begin{array}{l}\text { Moment and } \\
\text { Shear }\end{array}$} & \multicolumn{4}{|c|}{ Floor System } \\
\hline & & \multicolumn{2}{|c|}{$\begin{array}{c}\text { Model-A } \\
\text { Regular span Structure } \\
\left(20^{\prime}-0^{\prime \prime} \times 18^{\prime}-0^{\prime \prime}\right) \\
\text { GRID- E }\end{array}$} & \multicolumn{2}{|c|}{$\begin{array}{c}\text { Model-B } \\
\text { Longer span Structure } \\
\left(33^{\prime}-4^{\prime \prime} \times 30^{\prime}-0^{\prime \prime}\right) \\
\text { GRID- C }\end{array}$} \\
\hline \multirow{3}{*}{ Beam } & $\begin{array}{l}\text { Support } \\
(\mathrm{k}-\mathrm{ft})\end{array}$ & \multicolumn{2}{|c|}{$\begin{array}{l}+\mathrm{M}_{\mathrm{E} 1}=102.89 \\
+\mathrm{M}_{\mathrm{E} 2}=99.00 \\
-\mathrm{M}_{\mathrm{E} 1}=234.03 \\
-\mathrm{M}_{\mathrm{E} 2}=304.70\end{array}$} & \multicolumn{2}{|c|}{$\begin{aligned}+\mathrm{M}_{\mathrm{CA}} & =70.48 \\
+\mathrm{M}_{\mathrm{CB}} & =0 \\
-\mathrm{M}_{\mathrm{CA}} & =738.61 \\
-\mathrm{M}_{\mathrm{CB}} & =1277.13\end{aligned}$} \\
\hline & Mid Span (k-ft) & \multicolumn{2}{|c|}{$+\mathrm{M}_{\mathrm{E}}=127.65$} & \multicolumn{2}{|c|}{$+\mathrm{M}_{\mathrm{C}}=639.97$} \\
\hline & Shear $V_{u}$, Kip & \multicolumn{2}{|c|}{66.66} & \multicolumn{2}{|c|}{165.53} \\
\hline \multirow{2}{*}{$\begin{array}{l}\text { Columns at Different } \\
\text { Floor System }\end{array}$} & \multirow{2}{*}{$\begin{array}{l}\text { Moment and } \\
\text { Axial Force }\end{array}$} & \multicolumn{2}{|c|}{$\begin{array}{l}\text { STAAD-Pro Analysis } \\
\text { about } x \text { - axis of Column } \\
\text { C-2 }\end{array}$} & \multicolumn{2}{|c|}{$\begin{array}{l}\text { STAAD-Pro Analysis } \\
\text { about } y \text { - axis of } \\
\text { Column C-2 }\end{array}$} \\
\hline & & $\begin{array}{l}\text { Model-A } \\
\text { Regular } \\
\text { span }\end{array}$ & $\begin{array}{l}\text { Model-B } \\
\text { Longer } \\
\text { span }\end{array}$ & $\begin{array}{l}\text { Model-A } \\
\text { Regular } \\
\text { span }\end{array}$ & $\begin{array}{l}\text { Model-B } \\
\text { Longer } \\
\text { span }\end{array}$ \\
\hline \multirow{2}{*}{$\begin{array}{l}\text { Flat slab floor system } \\
\text { (Ground floor) }\end{array}$} & Moment (k-ft) & 9.14 & +169.61 & 32.14 & -11.63 \\
\hline & Axial force, (kip) & 1460 & 5070 & 1460 & 5070 \\
\hline \multirow{2}{*}{$\begin{array}{l}\text { Edge supported floor } \\
\text { system (Third floor) }\end{array}$} & Moment, (k-ft) & -93.88 & -132.78 & -53.21 & -290.65 \\
\hline & Axial force, (kip) & 1090 & 2660 & 917.12 & 2660 \\
\hline \multirow{2}{*}{$\begin{array}{l}\text { Flat plate floor system } \\
\text { (Fourth floor) }\end{array}$} & Moment, (k-ft) & -32.01 & +114.82 & 43.02 & -82.18 \\
\hline & Axial force, (kip) & 912.12 & 2650 & 781.23 & 2650 \\
\hline \multirow[b]{2}{*}{ Mat Foundation } & \multicolumn{5}{|c|}{ Moment, Eccentricity, Axial Load } \\
\hline & \multicolumn{2}{|c|}{$\begin{array}{c}\text { Model-A } \\
\text { Regular span Structure } \\
\left(20^{\prime}-0^{\prime \prime} \times 18^{\prime}-0^{\prime \prime}\right)\end{array}$} & \multicolumn{3}{|c|}{$\begin{array}{c}\text { Model-B } \\
\text { Longer span Structure } \\
\left(33^{\prime}-4^{\prime \prime} * 30^{\prime}-0^{\prime \prime}\right)\end{array}$} \\
\hline Factored Moment & \multicolumn{2}{|c|}{ - $7714.37 \mathrm{k}-\mathrm{ft}$} & \multicolumn{3}{|c|}{$-19380.58 \mathrm{k}-\mathrm{ft}$} \\
\hline $\mathrm{M}_{\mathrm{X}}$ at long direction & \multicolumn{2}{|c|}{$-33547.69 \mathrm{k}-\mathrm{ft}$} & \multicolumn{3}{|c|}{$-35440.62 \mathrm{k}-\mathrm{ft}$} \\
\hline $\mathrm{M}_{\mathrm{Y}}$ at long direction & \multicolumn{2}{|c|}{$-28893.68 \mathrm{k}-\mathrm{ft}$} & \multicolumn{3}{|c|}{$64318.16 \mathrm{k}-\mathrm{ft}$} \\
\hline $\mathrm{M}_{\mathrm{X}}$ at short direction & \multicolumn{2}{|c|}{$-28893.68 \mathrm{k}-\mathrm{ft}$} & \multicolumn{3}{|c|}{$64318.16 \mathrm{k}-\mathrm{ft}$} \\
\hline $\mathrm{M}_{\mathrm{Y}}$ at short direction & \multicolumn{2}{|c|}{$-33547.69 \mathrm{k}-\mathrm{ft}$} & \multicolumn{3}{|c|}{$-35440.62 \mathrm{k}-\mathrm{ft}$} \\
\hline $\begin{array}{l}\text { Eccentricity in long } \\
\text { direction }\end{array}$ & \multicolumn{2}{|c|}{$-0.745 \mathrm{ft}$} & \multicolumn{3}{|c|}{$-0.810 \mathrm{ft}$} \\
\hline $\begin{array}{l}\text { Eccentricity in transverse } \\
\text { direction }\end{array}$ & -0.8 & $65 \mathrm{ft}$ & & $+1.47 \mathrm{ft}$ & \\
\hline Axial load on mat & 3878 & $.46 \mathrm{k}$ & & 43753.85 & \\
\hline
\end{tabular}




\section{LIST OF FIGURES}
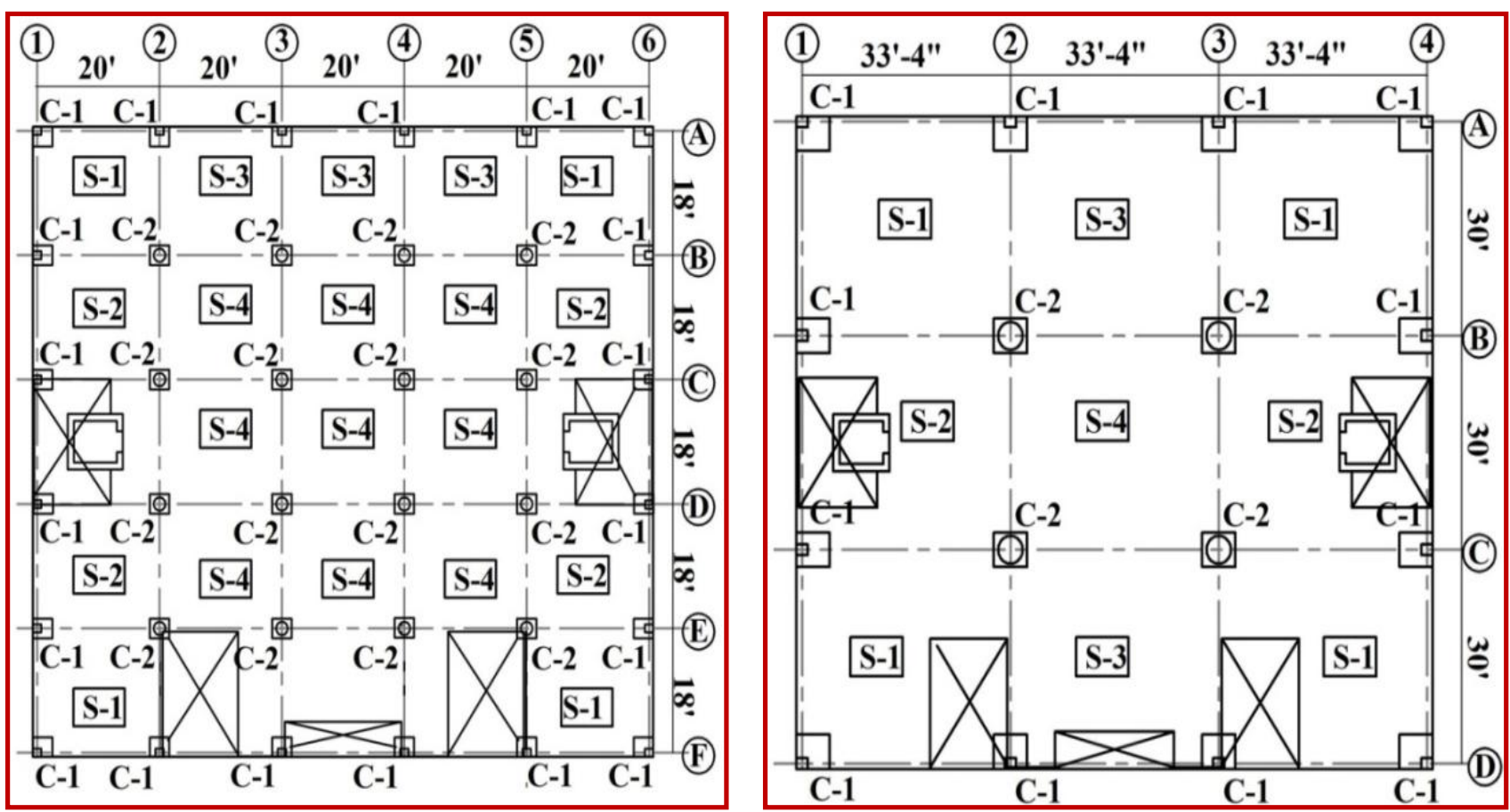

Fig-1: Ground Floor Column Layout of Model-A (Left) \& Model-B (Right)
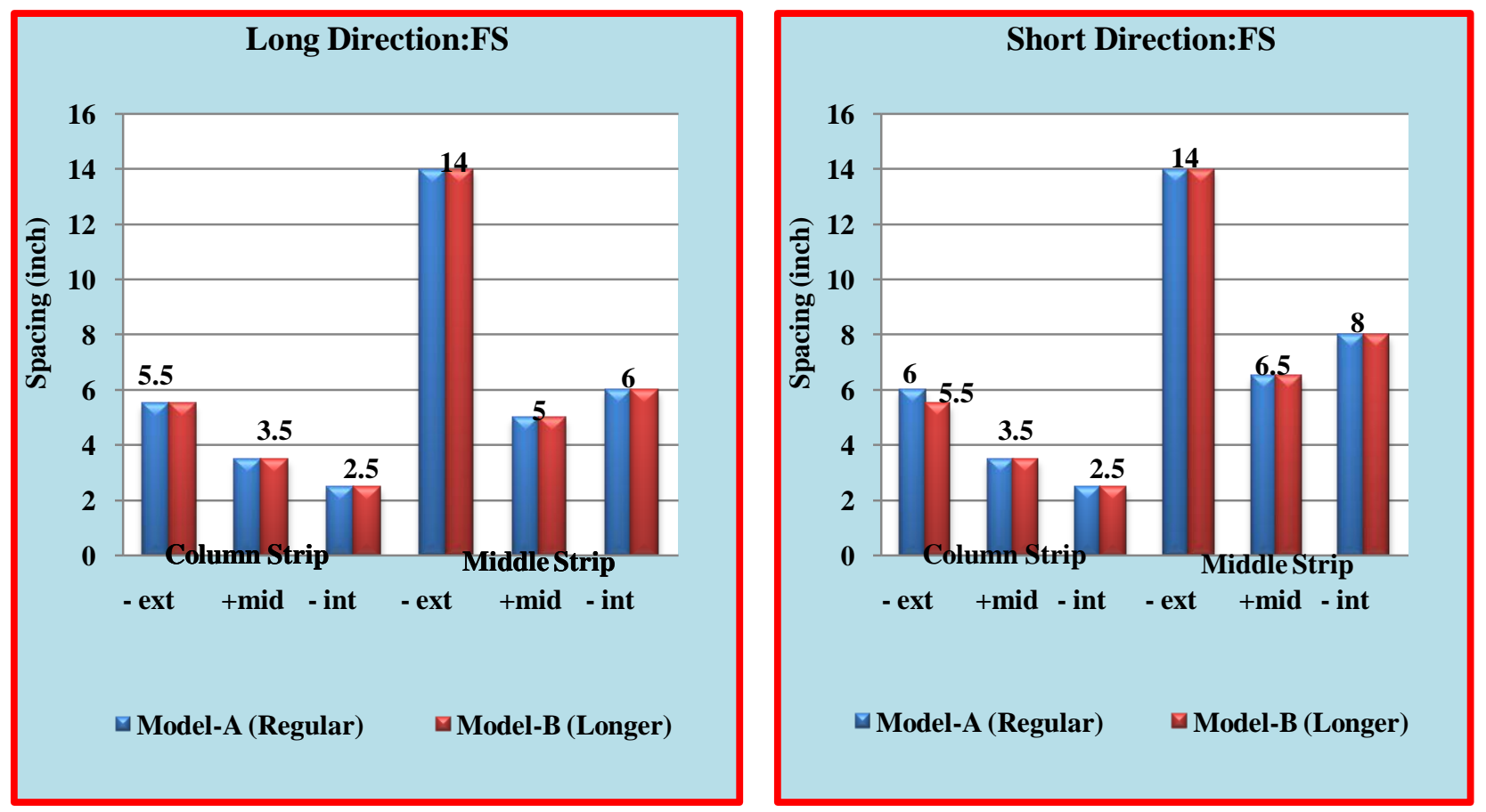

Fig-2: Details of basement slab reinforcement arrangement of panel S-1: Flat Slab (FS) 

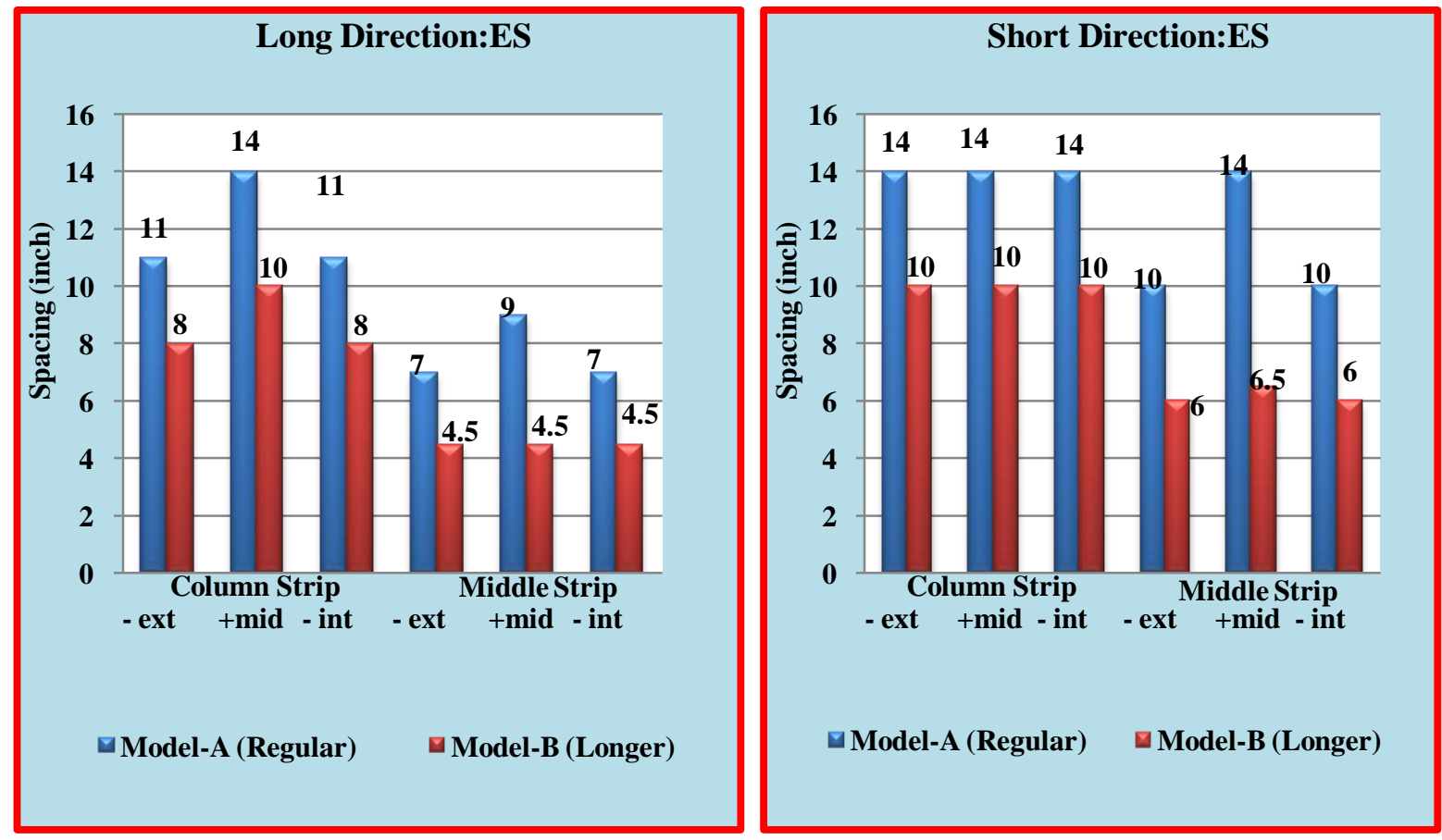

Fig-3: Details of $1^{\text {st }} \sim 3^{\text {rd }}$ Floors reinforcement arrangement of panel S-1: Edge Supported Slab (ES)

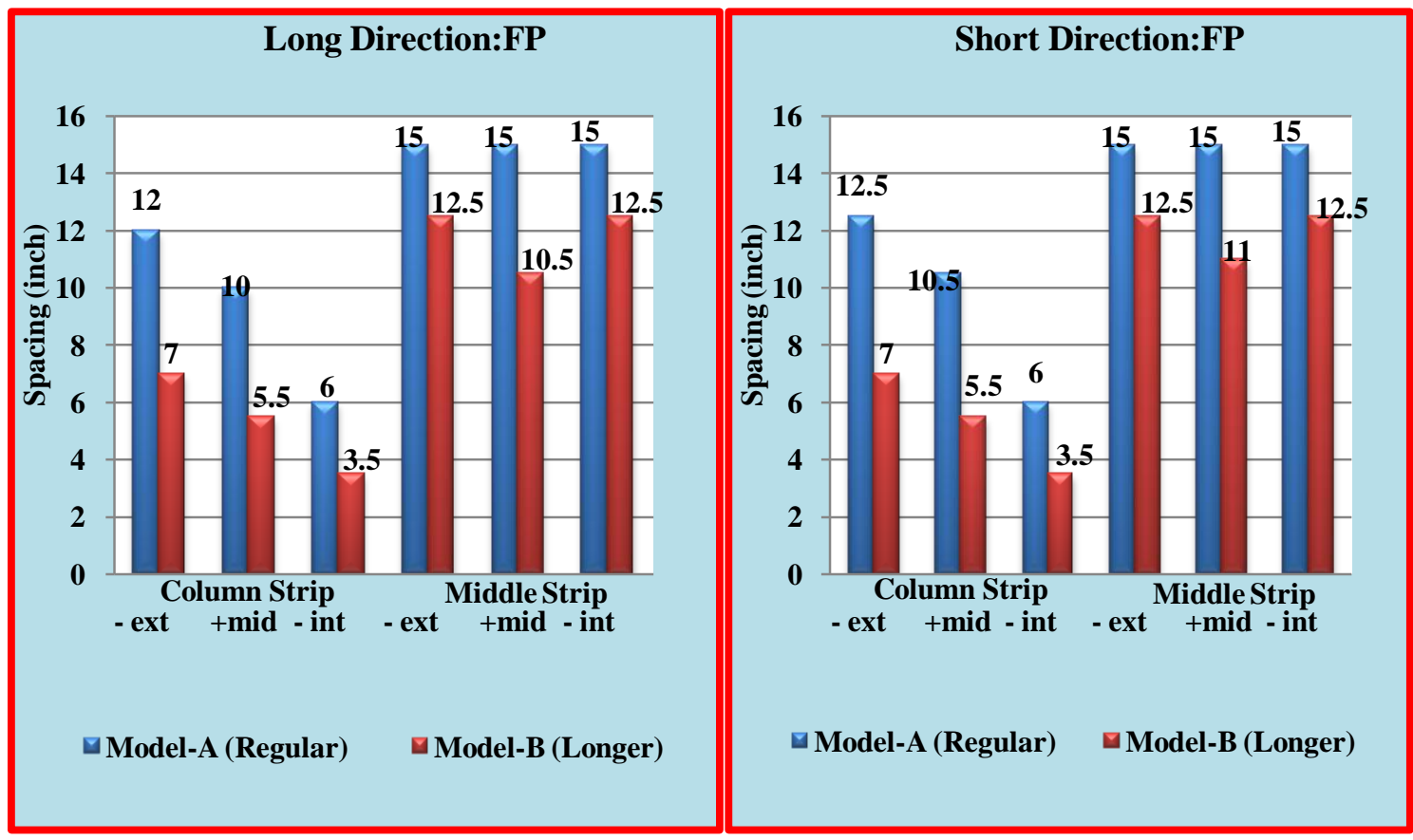

Fig-4: Details of 4th $\sim 9$ th Floors reinforcement arrangement of panel (S-1): Flat Plate Slab (FP) 


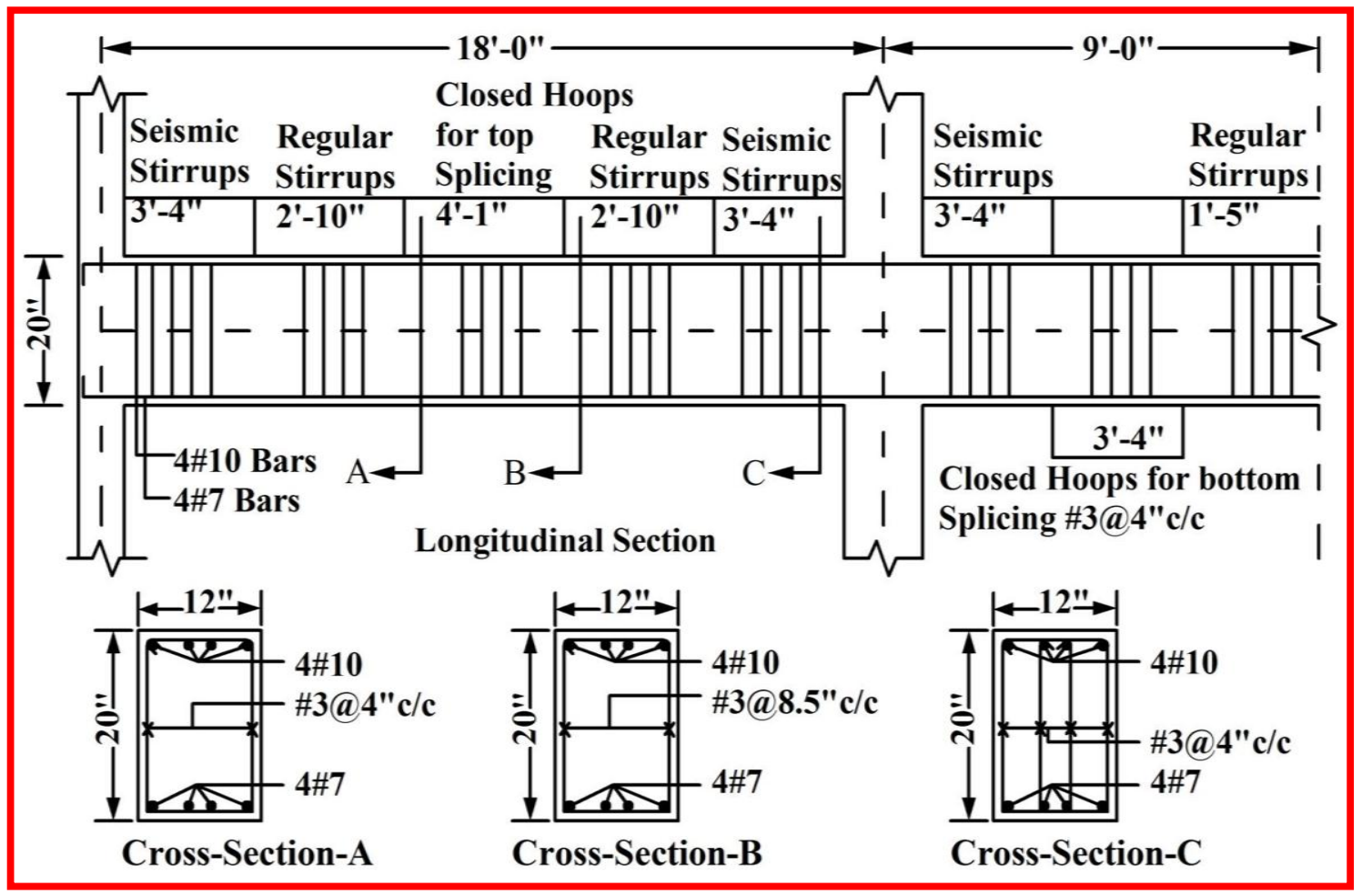

Fig-5: Reinforcement details of Beams-Frame 1 6 at $3^{\text {rd }}$ floor of Model-A

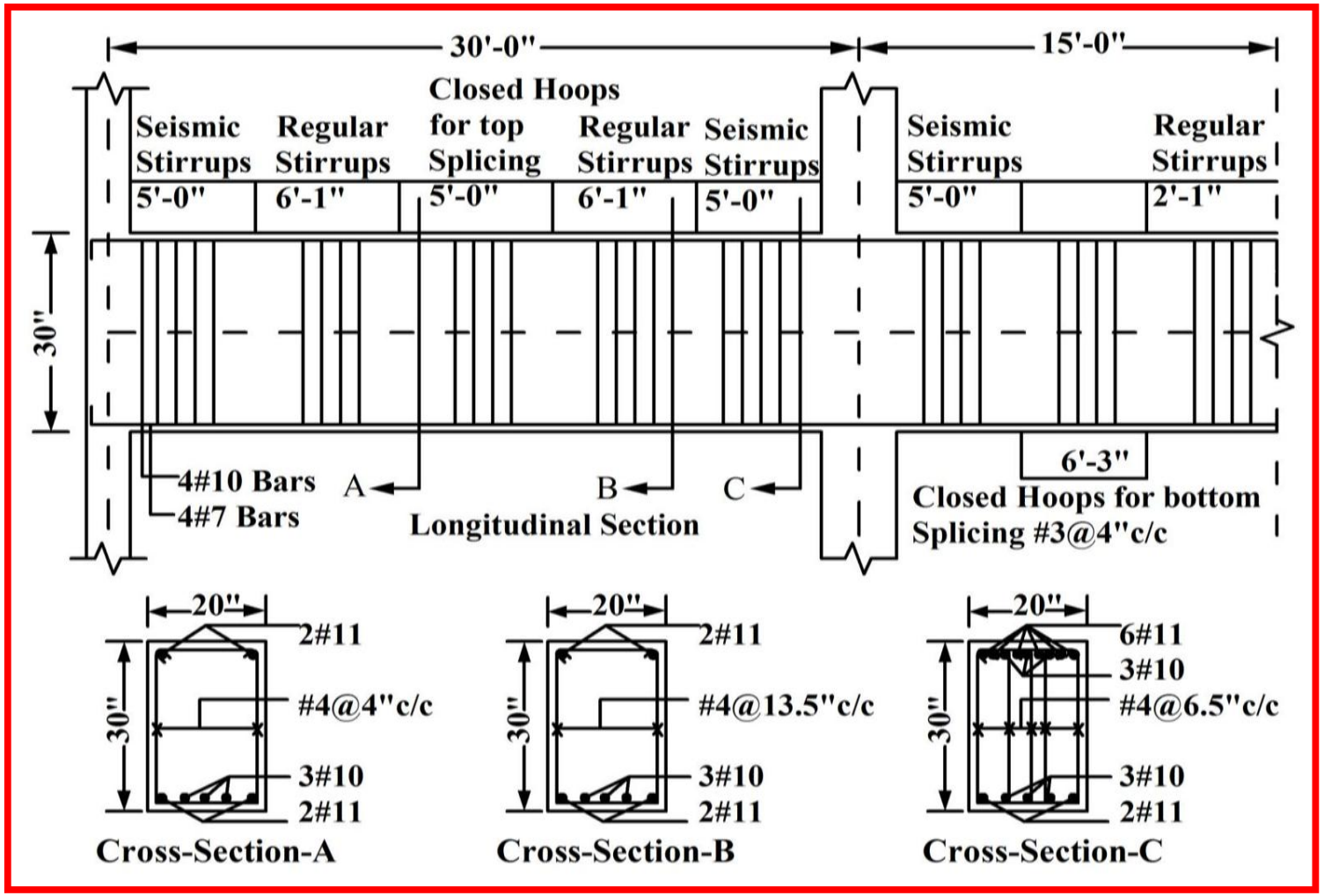

Fig-6: Reinforcement details of Beams-Frame 1 4 at $3^{\text {rd }}$ floor of Model-B 


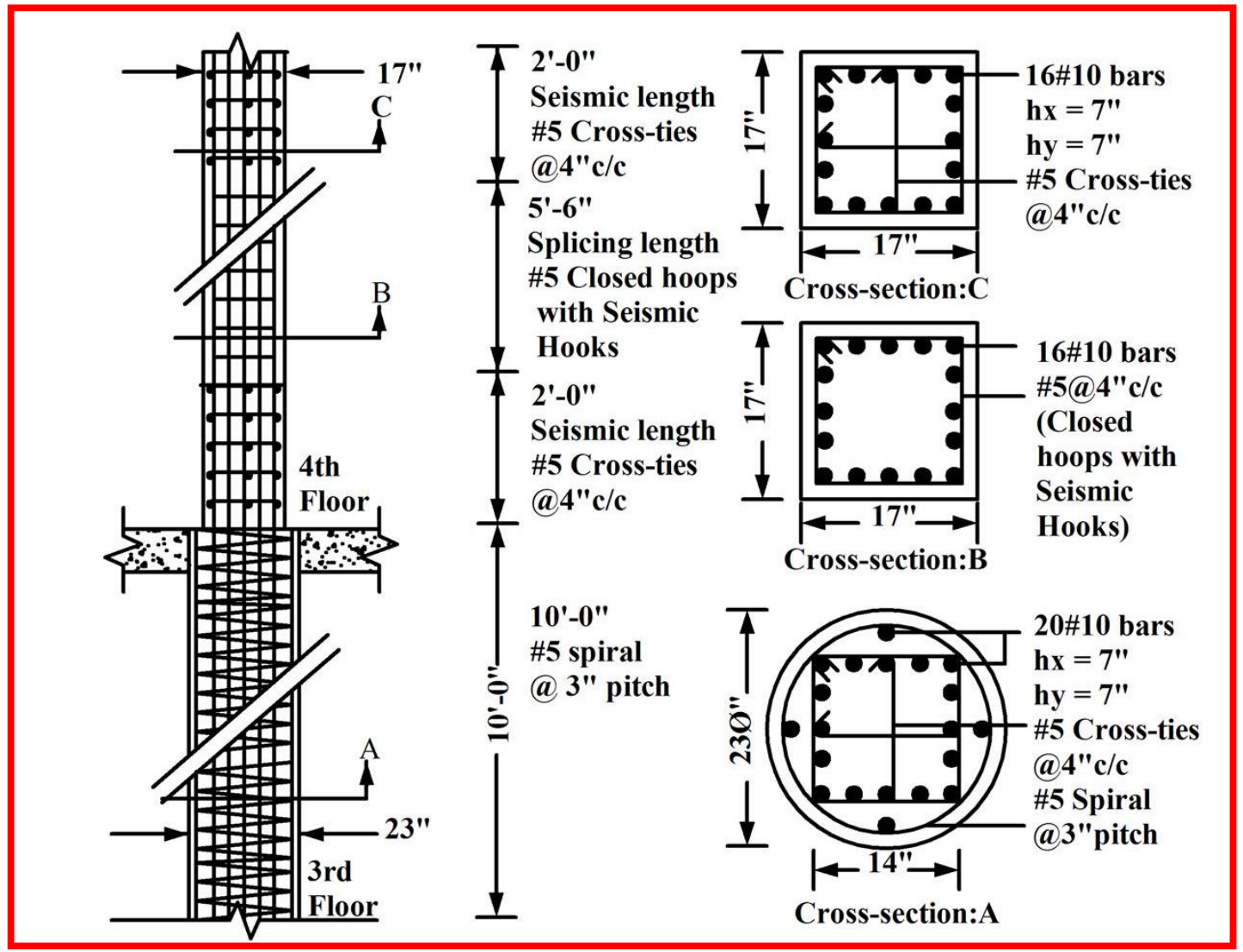

Fig-7: Details of Cross-section of column C2 at $3^{\text {rd }}$ and $4^{\text {th }}$ floor of Model-A

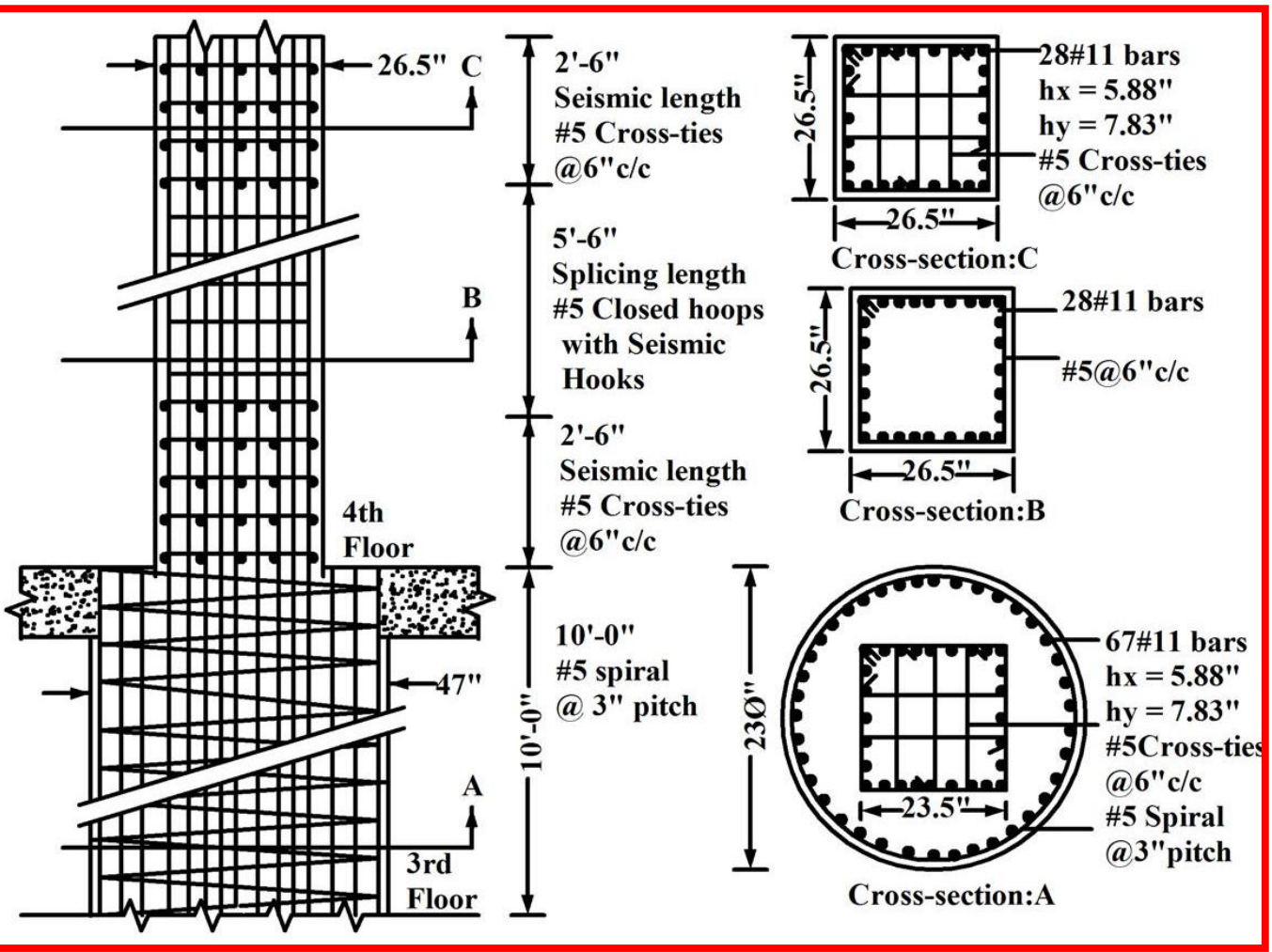

Fig-8: Details of Cross-section of column C2 at $3^{\text {rd }}$ and $4^{\text {th }}$ floor of Model-B 


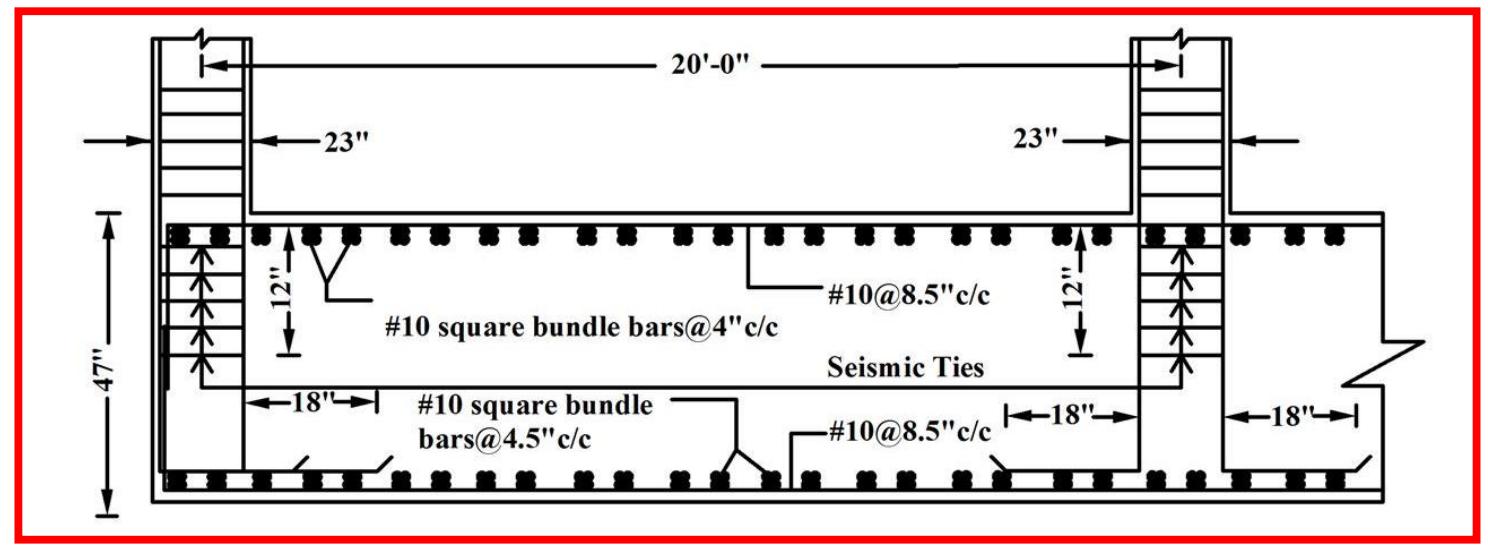

Fig-9: Details of A-A section of Mat of Model-A

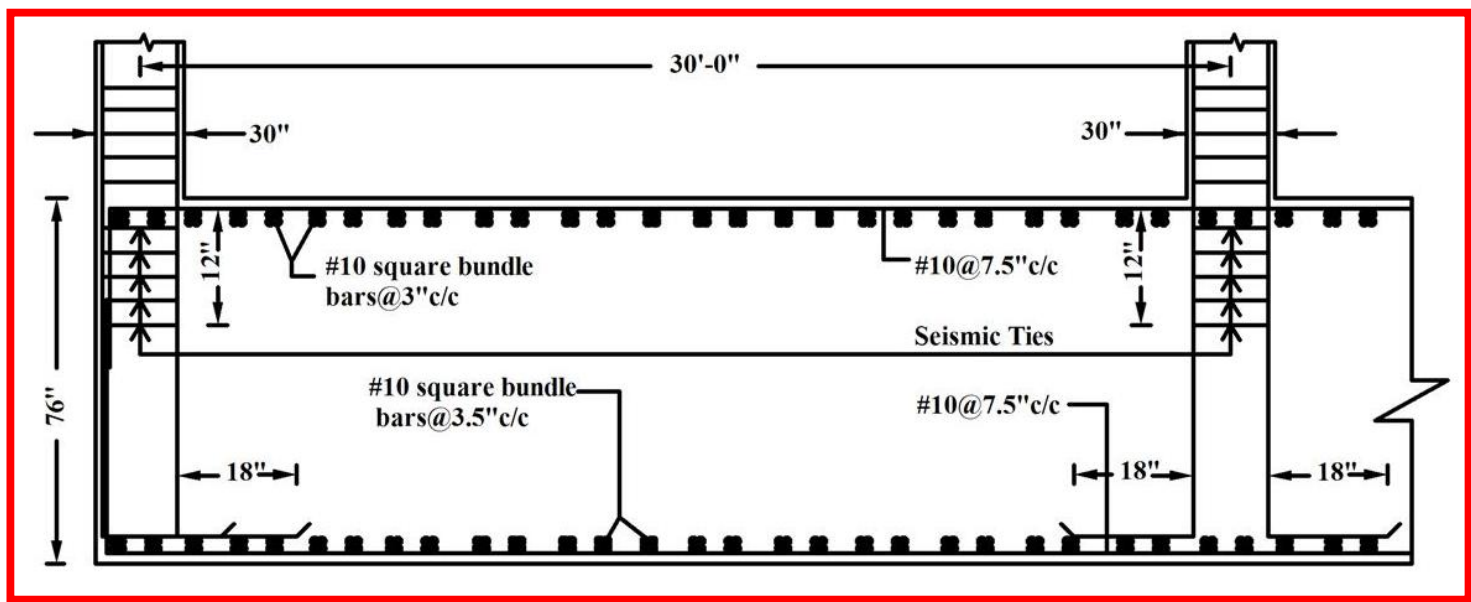

Fig-10: Details of A-A section of Mat of Model-B

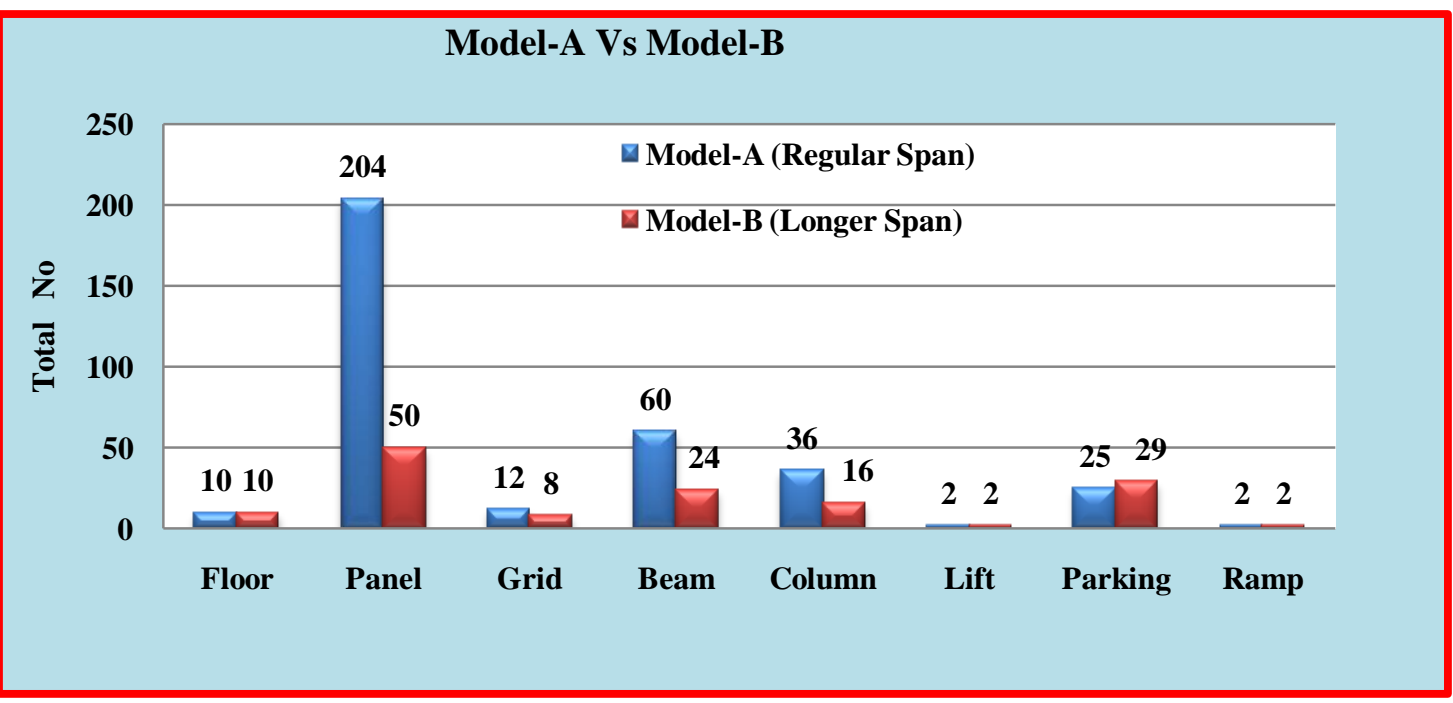

Fig-11: Comparison of Model-A \& Model-B based on Total no of components 


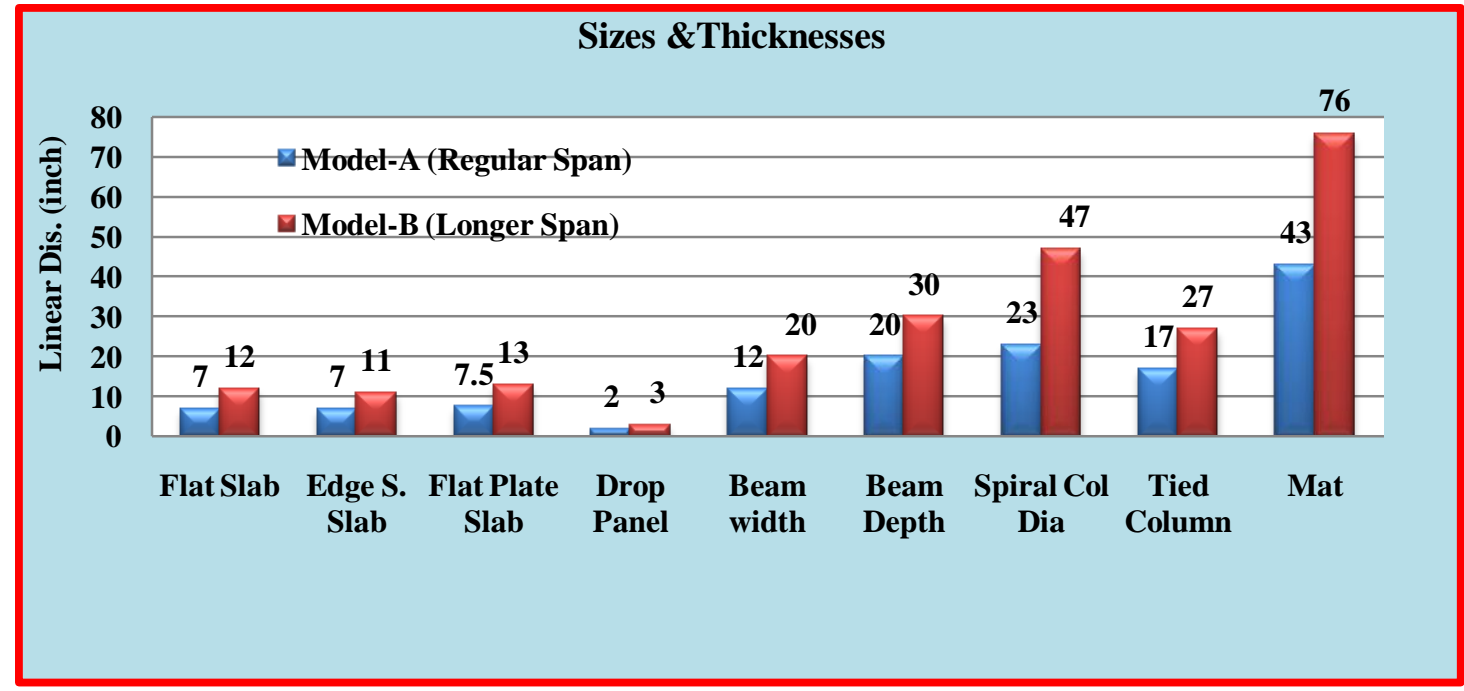

Fig-12: Comparison of Model-A \& B based on sizes \& thickness of structural components

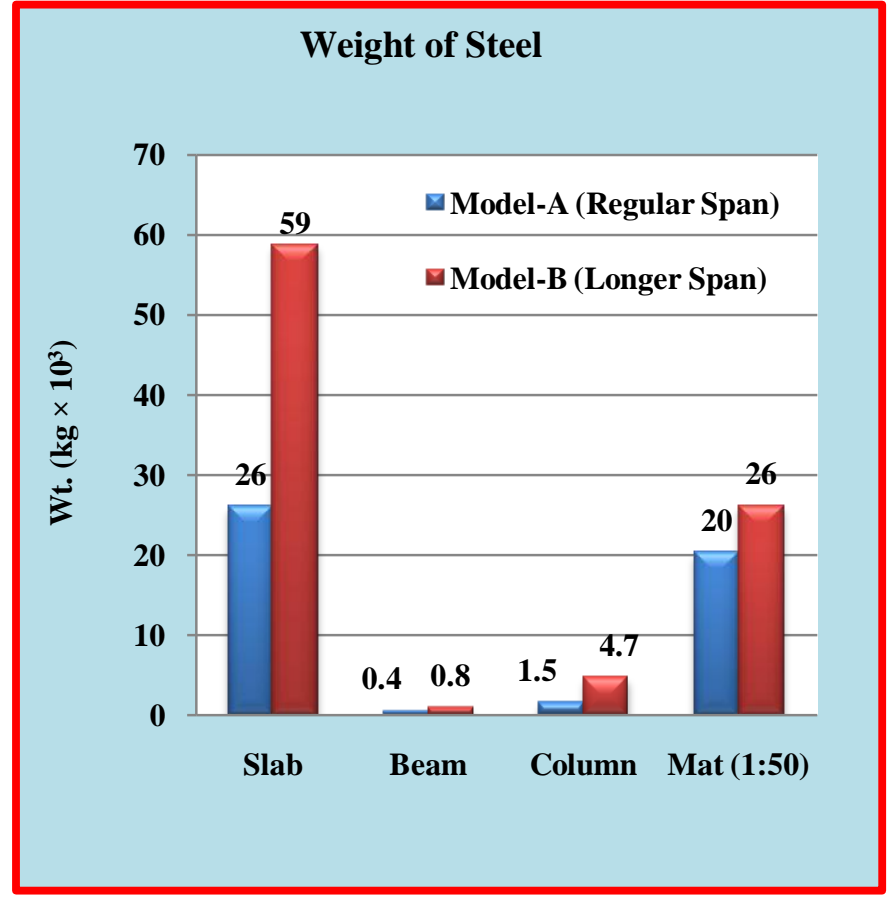

Fig-13: Comparison of Model-A \& B based on weight of steel

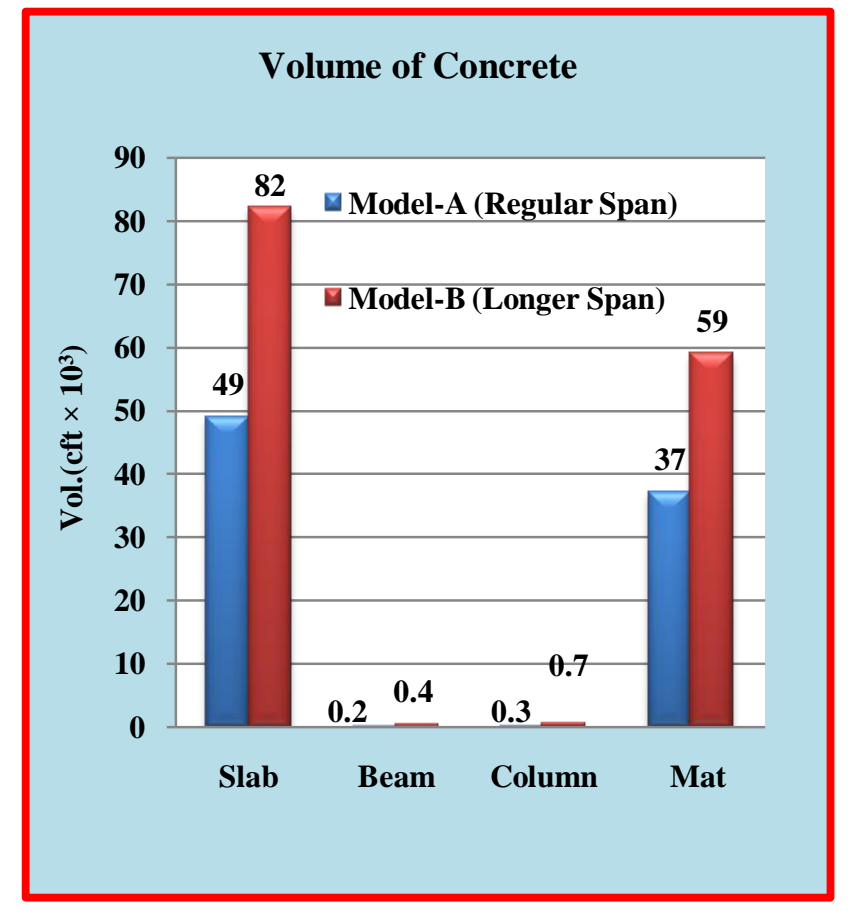

Fig-14: Comparison of Model-A \& B based on volume of Concrete 